Сурков О. О., к.військ.н.

Центр воєнно-стратегічних досліджень Національного університету оборони України імені Івана Черняховського, м. Київ

\title{
Формування інтегрованої системи управління ризиками як складової системи оборонного планування
}

Резюме. У статті запропоновано підхід до формування інтегрованої системи управління ризиками як складової системи оборонного планування з функціями системного аналізу розвитку спроможностей сил оборони та управління ризиками, яка передбачена завданням оборонної реформи. Система надасть можливість відповідним посадовим особам приймати виважені рішення в ході оборонного менеджменту 3 метою максимізації позитивних і мінімізації негативних наслідків (ризиків) прийнятих рішень в умовах невизначеності й економії ресурсів.

Ключові слова: інтегрована система, управління ризиками, оборонне планування, оборонна реформа, розвиток спроможностей, сили оборони.

Постановка проблеми. Однією 3 оперативних цілей оборонної реформи в Україні [1] визначено створення до кінця 2017 року інтегрованої системи управління ризиками як складової системи оборонного планування, яка дасть змогу уникнути стратегічних помилок, що можуть призвести до значних втрат у майбутньому, дозволить підвищити якість проведення оборонного планування сил оборони, сприятиме формуванню їх необхідних оперативних (бойових, спеціальних) спроможностей.

Для досягнення цієї оперативної цілі визначені завдання та результативні (індикативні) показники [1], а також відповідальні за виконання (МО України разом 3 іншими складовими сил оборони за підтримки РНБО України). При цьому сплановано (термін виконання - до кінця 2017 року) створення процесу систематичного моніторингу та системи аналізу розвитку сил оборони та іiі складових через створення робочого органу та формування відповідної структури 3 функціями системного аналізу розвитку сил оборони.

На сьогодні можна вважати, що створено робочий орган 3 функціями моніторингу й оцінювання виконання Державних програм (планів) розвитку сил оборони - Комітет реформ МО України та 3С України. Однак досі не сформовано відповідної структури з функціями системного аналізу розвитку сил оборони, яку слід будувати 3 урахуванням наявних спроможностей, організаційних i ресурсних можливостей, всебічних обмежень та позитивного досвіду зарубіжних країн. Наукові і військові фахівці (ризик-менеджери) у складі сформованої структури мають забезпечувати об'єктивний системний аналіз

результативності рішень, очікуваного ефекту та впливу на кінцевий результат не лише під час оборонної реформи, а й в ході оборонного планування, яке характеризується циклічністю i спрямоване на планування реалізації стратегії розвитку спроможностей Збройних Сил та інших складових сил оборони.

Викладення основного матеріалу. Проведений аналіз підходів до оцінювання ризиків у ході довгострокового оборонного планування [3] показав:

1. Процедура оцінювання ризиків потребує особливої уваги та комплексного підходу в ході оборонного планування, наявності відповідного науково-методичного апарату оцінювання ризиків під час аналізу безпекового середовища 3 урахуванням визначеної оборонної політики (стратегіi), наявних i необхідних спроможностей військ (сил) та ресурсних можливостей держави під час планування заходів із розвитку спроможностей складових сил оборони, які необхідно підтримувати i нарощувати (модернізувати), формувати нові й утилізовувати зайві (надлишкові), а також забезпечення ресурсами на довгострокову перспективу.

2. Аналіз зовнішніх i внутрішніх чинників, які впливають на воєнну безпеку держави, існуючих методів досліджень та науково-методичних підходів дає змогу стверджувати, що ризики є прогнозованими, залежать від ряду чинників, якими можна управляти або реагувати на них у ході планування та вироблення варіантів рішення.

3. Щоб уникнути стратегічних помилок, які можуть призвести до значних втрат у майбутньому (перевитрат фінансових ресурсів, неефективного використання економічного потенціалу держави тощо), необхідно мати 
відповідний науково-методичний апарат оцінювання ризиків та управління ними в ході оборонного планування, а також програмне забезпечення для комплексного оцінювання результативності й ефективності прийнятих рішень посадових осіб без надмірних обчислень і затрат часу.

4. Мінімізація ризиків та управління ними в ході оборонного планування сприятиме ефективному плануванню заходів, спрямованих на забезпечення обороноздатності держави, та можливості коригування ризик-стратегії залежно від обраних пріоритетів, стратегічних цілей i ресурсних можливостей держави.
Система управління ризиками - це сукупність підсистем (процедур) та їх елементів (об'єктів, суб'єктів, етапів, кроків, заходів), які перебувають у певних відносинах $\mathrm{i}$ зв'язках один з одним та спільно забезпечують вирішення конкретної проблеми із максимізації позитивних і мінімізації негативних наслідків (ризиків) прийнятих рішень в умовах невизначеності й економії ресурсів.

За результатами аналізу наявних наукових методів, а також останніх досліджень і публікацій [3-13] щодо оцінювання ризиків та управління ними створено i запропоновано комплексну модель оцінювання ризиків та управління ними в ході оборонного планування, структура якої наведена на рис. 1.

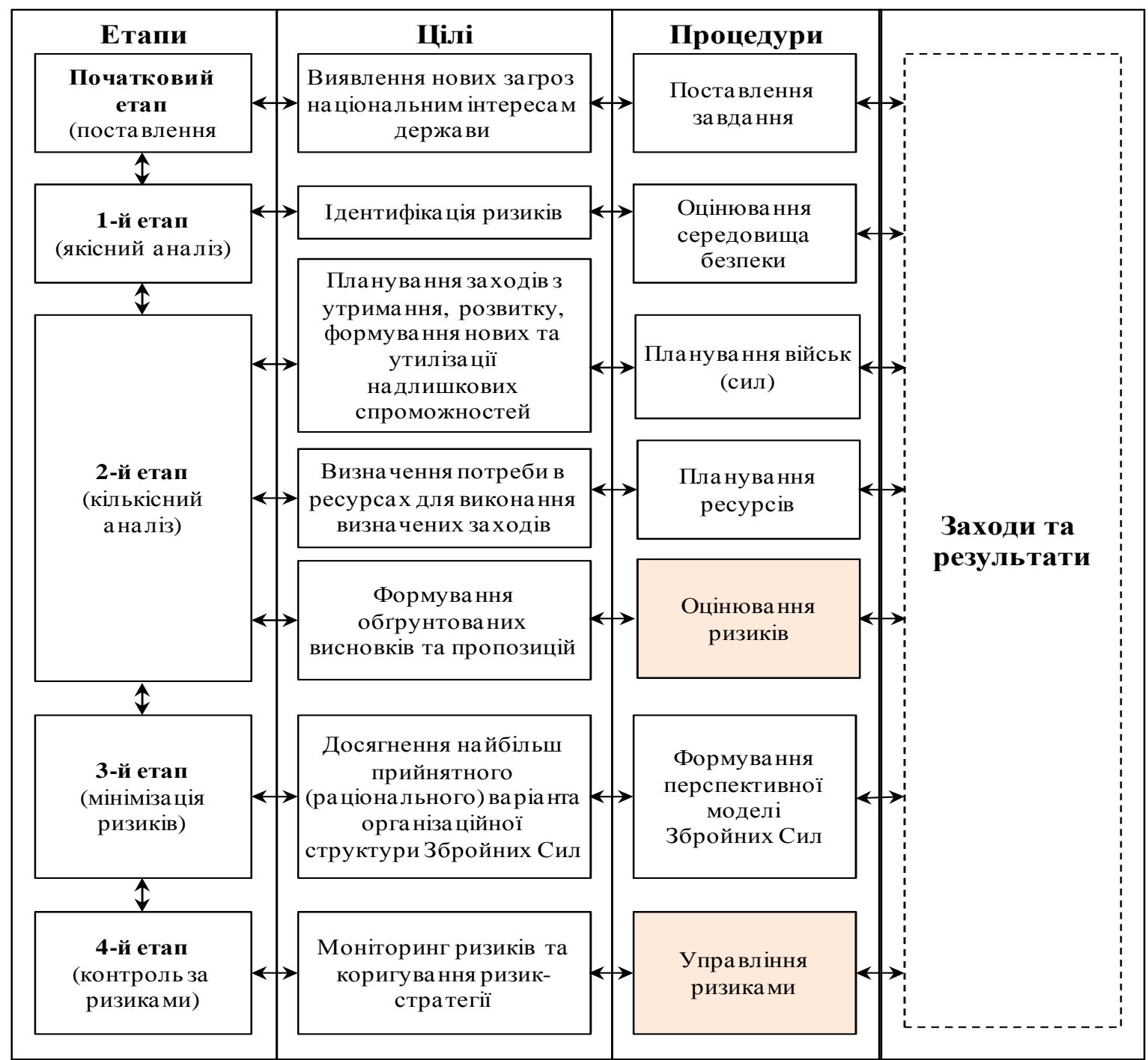

Рис. 1. Структура комплексної моделі оцінювання ризиків та управління ними в ході оборонного планування

У побудованій комплексній моделі вирізняють такі етапи оцінювання ризиків та управління ними:

якісне оцінювання ризиків;

кількісне оцінювання ризиків;

мінімізація ризиків;

контроль (моніторинг) за ризиками.
Цим етапам передує початковий етап поставлення завдань, у тому числі визначення обмежень та припущень.

Метою якісного оцінювання ризиків $\epsilon$ виявлення основних видів ризиків (очікуваних викликів і загроз), що впливають на загальний процес. Це дає можливість вже на початковому 
етапі аналізу наочно оцінити ступінь ризику залежно від кількісного складу ризиків і відмовитися від втілення в життя певного рішення.

Результати якісного аналізу ризиків $\epsilon$ вхідною інформацією для проведення кількісного аналізу, тобто аналізу спланованих заходів, потреби в ресурсах та силах на основі очікуваних викликів і загроз, наявних під час виконання конкретного завдання (алгоритму ухвалення рішення).

На етапі кількісного аналізу за допомогою, насамперед системного аналізу, а також відповідних науково-методичних апаратів оцінювання, вираховують числові значення величин (коефіцієнти, відсотки) обраних імовірнісних ризиків і рівень ризику об'єкта в цілому, можливий збиток та імовірність прояву ризиків.

На етапі мінімізації ризиків розглядають декілька варіантів дій (рішень, організаційної структури) та застосовують відповідні коефіцієнти важливості заходів (елементів), за обраними критеріями обирають найбільш прийнятний (раціональний) варіант, уточнюють основні завдання, склад, ресурси, спроможності, яких треба досягти, і складають програми (плани).

На заключному етапі (контролю за ризиками) необхідно здійснювати моніторинг виконання спланованих заходів, контролювати імовірність прояву ризиків у ході оборонного планування, аналізувати результати виконання цих заходів і рівень досягнення визначених стратегічних цілей, щоб мати можливість коригувати ризик-стратегії, шляхи досягнення цілей, ураховувати отримані результати під час наступних циклів оборонного планування або оперативного реагування керівництва на виникаючі проблеми у ході реалізації програмних і планових заходів.

У загальному вигляді інтегровану систему управління ризиками в ході оборонного планування можна навести схематично (рис. 2). Система має взаємодіяти 3 іншими метасистемами та системами у сфері оборони через інформаційні зв'язки. На основі варіанта інтегрованої системи управління ризиками в ході оборонного планування пропонується розробити їі організаційну схему функціонування.

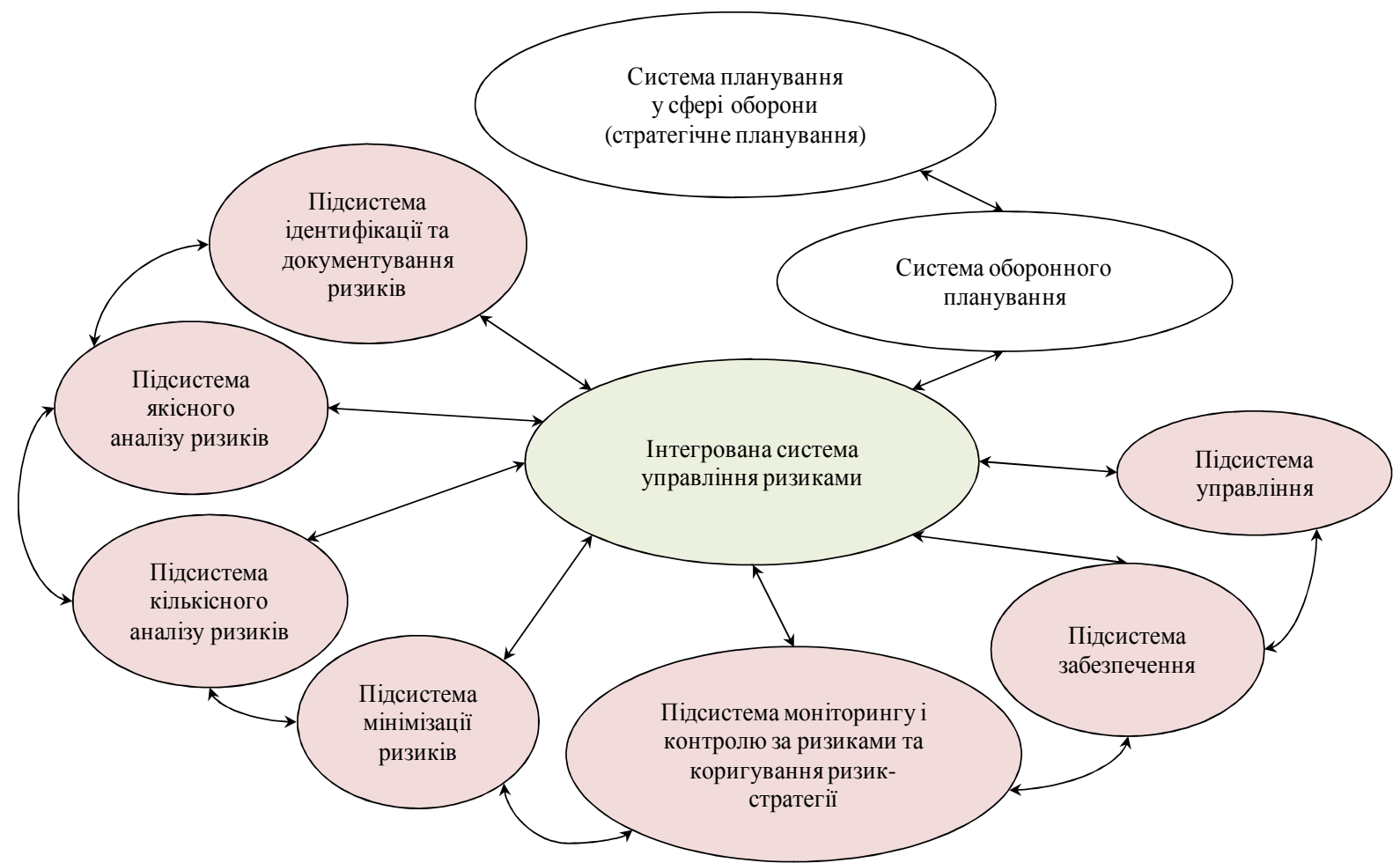

Рис. 2. Інтегрована система управління ризиками в ході оборонного планування

Крім того, на сьогодні актуальним завданням 3 проблематики впровадження системи управління ризиками в діяльність МО України разом 3 іншими складовими сил оборони за підтримки РНБО України $є$ визначення організаційної структури управління ризиками в ході оборонного планування. Зазначене сприятиме досягненню стратегічної цілі 2 оборонної реформи із забезпечення ефективності системи планування й управління ресурсами за рахунок управління ризиками та їх мінімізації в ході оборонного планування для більш ефективного й ощадного використання ресурсів у ході реалізації заходів відповідних програм і планів. 
Організаційно у схемі управління ризиками в ході оборонного планування i розвитку спроможностей сил оборони для МО України та ГШ ЗС України можуть бути такі суб' єкти управління (рис. 3):

головний ризик-менеджер;

відділ координації управління ризиками

у складі Департаменту воєнної політики, стратегічного планування та міжнародного співробітництва МО України;

ризик-менеджери інших структурних підрозділів МО України та ГШ ЗС України;

зарубіжні експерти (ризикологи);

інші ризик-менеджери (посадові особи за згодою, волонтери).

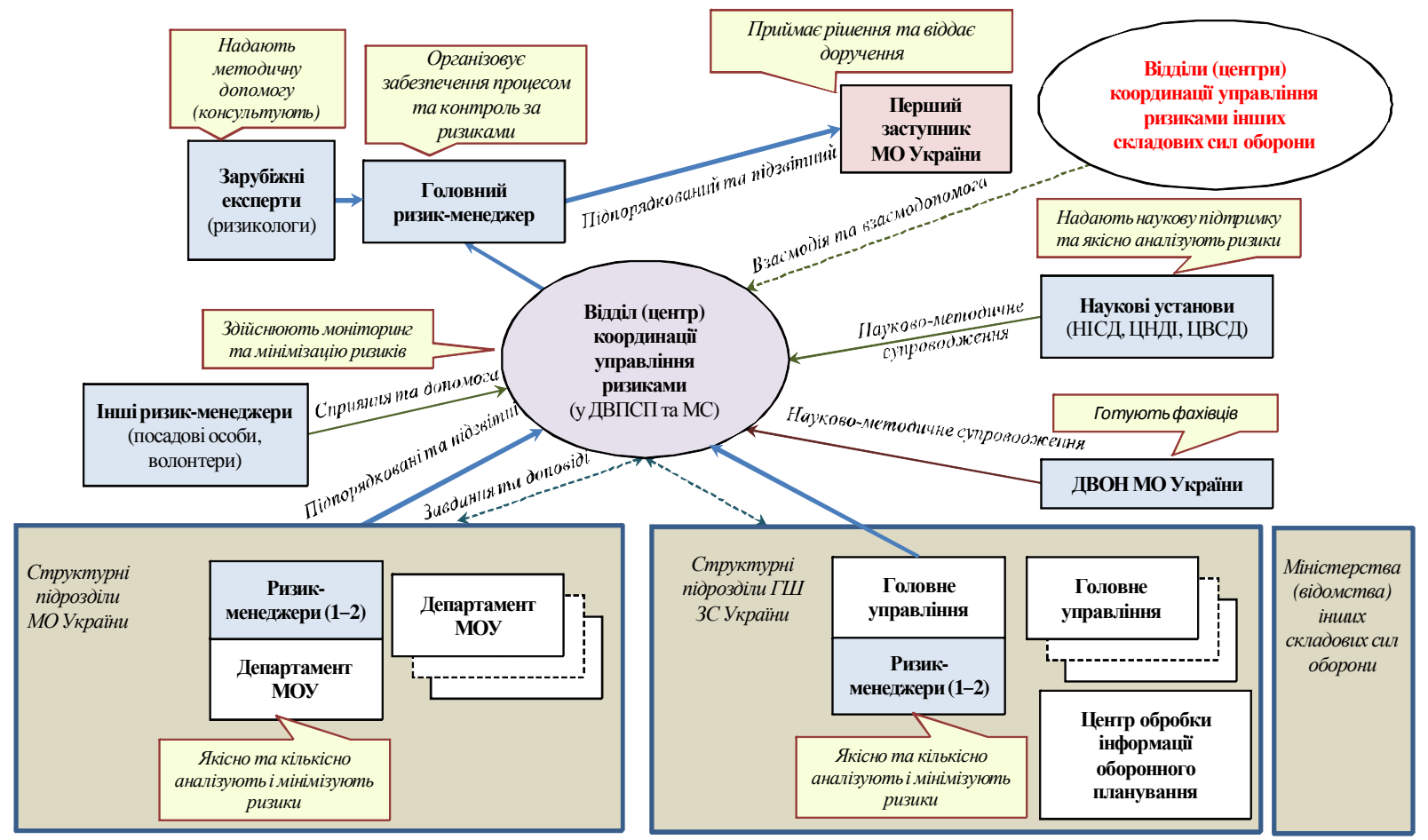

Рис. 3. Організаційна схема управління ризиками в ході оборонного планування

Структурні елементи системи управління ризиками орієнтовно матимуть таке призначення.

Головний ризик-менеджер повинен процес управління ризиками в МО України та ГШ ЗС України організовувати, управляти ним i контролювати його ефективність, а також взаємодіяти 3 головними ризикменеджерами інших складових сил оборони для вироблення пропозицій щодо мінімізації ризиків (зменшення їх впливу) та уникнення стратегічних помилок у прийнятті рішень керівництвом із розвитку спроможностей складових сил оборони, що можуть призвести до значних негативних наслідків.

Головний ризик-менеджер буде прямим начальником для штатних і позаштатних (у межах вирішення завдання управління ризиками) посадових осіб та підпорядковуватиметься безпосередньо першому заступнику Міністра оборони України. У ході планування розвитку спроможностей Збройних Сил та інших складових сил оборони головний ризикменеджер може виконувати функцію радника першого заступника Міністра оборони
України щодо мінімізації ризиків, що істотно впливають на розвиток спроможностей військ (сил), а також звітуватиме йому про результати своєї діяльності і підпорядкованих ризикменеджерів, у тому числі результати діяльності відділу координації управління ризиками. При цьому головний ризик-менеджер має бути незалежним експертом, погоджувати документи щодо розвитку спроможностей 3С України за результатами аналізу та пропозицій відділу координації управління ризиками i виконувати доручення першого заступника Міністра оборони України у межах своїх обов'язків.

Відділ координації управління ризиками пропонується створити у складі Департаменту воєнної політики, стратегічного планування та міжнародного співробітництва МО України (ДВПСП та МС), оскільки в ньому обробляють великий обсяг інформації з питань національної безпеки у воєнній сфері, сфері оборони i військового будівництва. У складі ДВПСП та МС є діловодство та структурні підрозділи, які опрацьовують питання стратегічного планування розвитку спроможностей 3С України. 
Відділ має стати основним органом в МО України, який збиратиме й оброблятиме інформацію про потенційні (наявні) ризики для їх моніторингу та мінімізації, а також розроблятиме ризик-стратегії зі зменшення впливу ризиків на розвиток спроможностей ЗС України. Основною функцією відділу передбачена координація управління ризиками в МО України та ЗС України для підтримання процесу прийняття рішень 3 розвитку спроможностей ЗС України та інших складових сил оборони. Фахівці відділу безпосередньо підпорядковуватимуться начальнику відділу та в межах основного призначення - головному ризик-менеджеру.

y межах виконання завдань 3 управління ризиками начальнику відділу пропонується підпорядкувати штатних (позаштатних) ризик-менеджерів структурних підрозділів МО України та ГШ ЗС України.

Ризик-менеджерів інших структурних підрозділів МО України та ГШ ЗС України на етапі запровадження системи управління ризиками слід призначити 3-поміж позаштатних спеціалістів, допущених до державної таємниці, зі значним досвідом роботи за певним напрямом та аналітичними здібностями. Завданнями їх діяльності слід визначити:

кількісний аналіз, оцінювання рівня ризиків та їх мінімізацію для досягнення визначених спроможностей;

управління ризиками на своєму рівні; узагальнення інформації щодо виявлення, ідентифікації, аналізу, оцінювання ризиків i результатів управління ними у структурних підрозділах.

Ризик-менеджерів інших структурних підрозділів МО України та ГШ ЗС України в межах вирішення завдання управління ризиками слід підпорядкувати начальнику відділу координації управління ризиками.

Також до діяльності можуть бути залучені за згодою інші ризик-менеджери (посадові особи), які працюють у наукових установах, волонтери та військові експерти.

Для виконання процедури оцінювання ризиків можуть бути використані існуючі методи, науково-методичний апарат і підходи, а також розроблені нові (у разі потреби) та вдосконалені наявні.

Нині однією 3 найуспішніших системних технологій, що дає змогу комплексно оцінювати вплив зовнішніх $\mathrm{i}$ внутрішніх чинників, сильні і слабкі сторони та можливості держави, що впливають на стан захищеності інтересів суспільства і держави, $\epsilon$
SWOT-аналіз, запропонований у 1965 році професорами Гарвардського університету для розроблення стратегії поведінки організації.

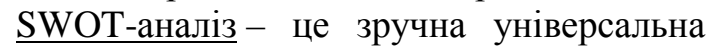
методологія, використовувана для розроблення стратегій у найрізноманітніших сферах життєдіяльності, i, за результатами досліджень, $\epsilon$ обов'язковим попереднім етапом під час підготовки стратегічних планів (рішень).

Дані, отримані в результаті застосування SWOT-аналізу, можуть слугувати базовими засадами для розроблення стратегічних цілей, допомогти ризик-менеджерам розробити ефективну стратегію врегулювання проблем оборонної політики. На жаль, SWOT-аналіз нині не застосовують в органах військового управління ЗС України.

В інтегрованій системі управління ризиками в ході оборонного планування в МО України та ЗС України слід передбачити такі елементи підтримання стану ефективного функціонування системи:

зарубіжних експертів (ризикологів) у сфері оборони;

науково-дослідні установи (НІСД, ЦНДІ ЗС України, ЦВСД НУОУ);

навчально-наукові установи МО України (ДВОН МО України, ВВНЗ).

Зарубіжні експерти (ризикологи) у сфері оборони братимуть участь у вирішенні проблемних питань впровадження інтегрованої системи управління ризиками в діяльність МО України та ЗС України: будуть радниками головного ризик-менеджера 3 питань управління ризиками в МО України та ЗС України і навчатимуть ризик-менеджерів та інших фахівців з оборонного планування.

Науково-дослідні установи будуть науково підтримувати i якісно аналізувати ризики; проводитимуть необхідні наукові дослідження (наукове супроводження) та розроблятимуть (удосконалюватимуть) науково-методичні апарати оцінювання ризиків та управління ними.

Навчально-наукові установи МО України в межах супроводження процесу управління ризиками готуватимуть фахівців 3 питань оборонного менеджменту, а також братимуть участь у процесі науково-методичного супроводження інтегрованої системи управління ризиками в МО України та ЗС України.

Для створення та функціонування зазначеного необхідно розробити Положення про організацію функціонування інтегрованої системи управління ризиками в Міністерстві оборони та Збройних Силах України, яке 
пропонується затвердити наказом Міністра оборони України. У Положенні слід визначити:

- призначення інтегрованої системи управління ризиками;

- основні завдання інтегрованої системи

управління ризиками;

- організаційну структуру;

- порядок організації, підзвітності та взаємодії;

- принципи управління ризиками

(завдання 2.2.1 згідно з [1]);

- інші питання (аналогічно структурам

існуючих положень про органи управління).

Основними напрямами 3 моніторингу стану реформування та розвитку Збройних Сил, оцінювання та контролю ризиків для коригування ризик-стратегії мають бути:

1) система управління;

2) стан кадрової політики;

3) військова освіта;

4) оснащеність ЗС України озброєнням та військовою технікою;

5) підготовка військ (сил);

6) матеріально-технічна забезпеченість військ (сил);

7) стан медичного забезпечення;

8) військова інфраструктура;

9) економічна і господарська діяльність;

10) стан утилізації компонентів ракетного палива, ракет, боєприпасів та озброєння, військової техніки;

11) стан фінансування.

Висновки. Таким чином, запропонована інтегрована система управління ризиками та на іiі основі - організаційна схема управління ризиками в ході оборонного планування дадуть змогу:

цілеспрямовано впливати на відповідних посадових осіб і підтримувати їх на етапі прийняття рішень для уникнення стратегічних помилок, які можуть призвести до значних втрат у майбутньому (перевитрат фінансових ресурсів, неефективного використання економічного потенціалу держави тощо);

підвищити якість оборонного планування на основі спроможностей у MO України та ЗС України 3 метою планування реалізації стратегії, цілі якої визначені під час стратегічного планування у сфері оборони;

об'єктивно оцінювати результативність рішень, очікуваний ефект і вплив на кінцевий результат;

відповідним посадовим особам в ході оборонного менеджменту приймати зважені рішення для максимізації позитивних i мінімізації негативних наслідків прийнятих рішень в умовах невизначеності;

запровадити сучасні євроатлантичні підходи й ефективну політику системи планування i управління ресурсами в МО України та 3С України; реалізувати виконання оперативної цілі 2.2 оборонної реформи в Україні.

На далі (після 2020 року) за умови ефективного впровадження інтегрованої системи управління ризиками іiі слід нарощувати та всебічно розвивати.

\section{Перспективою}

подальшого дослідження 3 урахуванням отриманих результатів $\epsilon$ розроблення (уточнення) принципів функціонування інтегрованої системи управління ризиками в ході виконання урядових програм (планів) розвитку складових сектору оборони згідно 3 визначеним завданням 2.2.1 [1].

\section{СПИСОК ВИКОРИСТАНОЇ ЛІТЕРАТУРИ}

1. Указ Президента України "Про Рішення РНБО України від 20.05.2016 "Про Стратегічний оборонний бюлетень України” від 06.06.2016 № 240/2016.

2. Про затвердження Військового стандарту ВСТ 01.004.006-2017(01) Видання № 1: станом на 28 квіт. 2017 р. - К.: МО Украӥни, 2017. - 177 c. (Нормативний документ Міністерства оборони Украӥни).

3. Сурков О.О. Аналіз підходів щодо оцінювання ризиків у ході довгострокового оборонного планування / О.О. Сурков // Зб. наук. праць ЦВСД НУОУ. - 2014. - № 2 (51). - С. 132-136.

4. Горбулін В.П. Стратегічне планування: вирішення проблем національної безпеки: монографія / В.П. Горбулін, А.Б. Качинський. - К.: НІСД, 2010. - 288 c.

5. Стрельбіцька Н.I. Становлення та розвиток міжнародних стандартів управління ризиками / Н.I. Стрельбіцька // Вісник КНТЕУ. - 2008. № 6. - C. 84-93.

6. Донець Л.І. Обгрунтування господарських рішень та оцінювання ризиків [Електронний ресурс] / Л.I. Донець. - Режим доступу: http://pidruchniki.ws/ 11750204/ ekonomika/ obgruntuvannya_ gospodarskih_ rishen_ta_ otsinyuvannya_rizikiv_donets_li].

7. Інтегрована модель управління ризиками / С.О. Кириченко, М.М. Лобко, Ф.В. Саганюк та ін.; за ред. Р.І. Тимошенка. - К.: Аграр Медіа Груп, 2013. - $156 \mathrm{c}$.

8. Богданович В.Ю. Спосіб формалізації стратегічного планування у сфері державного управління забезпеченням національної безпеки держави / В.Ю. Богданович, А.І. Семенченко // Стратегічна панорама. - 2006. - № 3. - С. 42-53. 
9. Вітлінський В.В. Ризикологія в економіці та підприємництві: монографія / В.В. Вітлінський, Г.І. Великоіваненко. - К.: КНЕУ, 2004. - 480 с.

10. Про затвердження Рекомендацій з організації та проведення оборонного огляду: станом на 13 трав. 2013 р. - К.: МО України, 2013. - 26 с. (Нормативний документ Міністерства оборони України).

11. Системный анализ в управлении: учеб. пособие / В.С. Анфилатов, А.А. Емельянов, А.А. Кукушкин; под ред. А.А. Емельянова. - М.: Финансы и статистика, 2002. - 368 с.
12. Орловский П.Н. Системный анализ: учеб. пособ. [для студ. экон. спец.] / П.Н. Орловский. - К.: Институт содержания и методов обучения, 1996. 360 c. - (Основные понятия, принципы, методология).

13. Сурков О.О. Методика оцінювання ризиків під час аналізу ресурсних можливостей держави щодо задоволення потреб Збройних Сил України / О.О. Сурков // Зб. наук. праць ЦВСД НУОУ.2016. - № 1 (56). - C. 69-74.

Стаття надійшла до редакції 19.06.2017

\section{Сурков О. А., к.воен.н.}

Центр военно-стратегических исследований Национального университета обороны Украины имени Ивана Черняховского, Киев

\section{Формирование интегрированной системы управления рисками как составляющей системы оборонного планирования}

Резюме. В статье предложен подход к формированию интегрированной системы управления рисками как составляющей системы оборонного планирования с функциями системного анализа развития способностей сил обороны и управления рисками, которая предусмотрена задачей оборонной реформы. Система даст возможность соответствующим должностным лицам принимать взвешенные решения в ходе оборонного менеджмента, с целью максимизации положительных и минимизации негативных последствий (рисков) принятых решений в условиях неопределенности и экономии ресурсов.

Ключевые слова: интегрированная система, управление рисками, оборонное планирование, военная реформа, развитие способностей, силы обороны.

\section{O. Surkov, Ph.D}

Center for Military and Strategic Studies of the National Defence University of Ukraine named after Ivan Chernyhovsky, Kyiv

Formation of an integrated risk management system as a component of the defense planning system

Resume. The article suggests an approach to the formation of an integrated risk management system as a component of the defense planning system with the functions of a system analysis of the development of capabilities of the defense forces and risk management, which is envisaged by the task of defense reform. The system will enable relevant officials to make informed decisions in the course of defense management, in order to maximize positive and minimize negative consequences (risks) of decisions taken in conditions of uncertainty and saving resources.

Keywords: integrated system, risk management, defense planning, military reform, development of capabilities, defense forces. 